\section{Human dignity and the future of the voluntary active euthanasia debate in South Africa}

To the Editor: In this letter, I reply to Dr Donkin's ${ }^{[1]}$ response to my article 'Human dignity and the future of the voluntary active euthanasia debate in South Africa, ${ }^{[2]}$ published in the May 2017 edition of the SAMJ.

I start with the question of whether individual autonomy is central to the definition of human dignity. Although the concept of human dignity has near-universal appeal, internationally several conceptions of its meaning exist. In South Africa (SA), our Constitutional Court has over the past generation often grappled with the concept in its jurisprudence. In the case of Barkhuizen $v$ Napier, ${ }^{[3]}$ the Constitutional Court explicitly held that 'Self-autonomy, or the ability to regulate one's own affairs, even to one's own detriment, is the very essence of freedom and a vital part of dignity. This position was echoed in MEC for Education: Kwazulu-Natal v Pillay ${ }^{[4]}$ where the majority of the Constitutional Court held that an 'entitlement to respect for the unique set of ends that the individual pursues' - which approximates to autonomy - is a 'necessary element of freedom and of dignity of any individual. Furthermore, the Supreme Court of Appeal held as follows in British American Tobacco South Africa (Pty) Ltd $v$ Minister of Health: ${ }^{[5]}$

'Recognising the role of freedom of expression in asserting the moral autonomy of individuals demonstrates the close links between freedom of expression and other constitutional rights such as human dignity, privacy and freedom. Underlying all these constitutional rights is the constitutional celebration of the possibility of morally autonomous human beings independently able to form opinions and act on them.'

Accordingly, there is solid authority for my proposition that, in SA law, individual autonomy is central to human dignity. Dr Donkin's accusation that so-called 'pro-euthanasia activists' frequently 'hijack' dignity and use it as a 'euphemism' for autonomy is therefore without merit. In our law, autonomy needs no euphemism - it is explicitly celebrated as a vital part of human dignity. This is the reality that will have to be confronted in any subsequent litigation about voluntary active euthanasia.

Next, Dr Donkin states that 'Jordaan failed to mention that individual autonomy can never be absolute.' This is not correct. I clearly stated in my article that human dignity, and per implication therefore individual autonomy, are not the only relevant considerations in the voluntary active euthanasia debate. In fact, I concluded my article by stating that 'It bears repetition that human dignity is not the only right that is relevant to this complex discourse. The question of whether or not voluntary active euthanasia is required by SA's human rights system must be answered by carefully balancing all rights that are relevant to the subject.' The balancing of rights is a standard principle of our law that goes without saying.

The term 'autonomy' is used, with somewhat different meanings, in fields as diverse as law and psychology, and one must be careful to avoid conflating these different uses. In particular, questions of free will must be distinguished from the legal meaning of autonomy. John Stuart Mill refers to this very distinction in the first sentence of $\mathrm{On}$ Liberty ${ }^{[6]}$ (in somewhat old-fashioned language): 'The subject of this Essay is not the so-called Liberty of the Will, so unfortunately opposed to the misnamed doctrine of Philosophical Necessity; but Civil, or Social Liberty: the nature and limits of the power which can be legitimately exercised by society over the individual.' As such, when I propose that autonomy is a central component of human dignity, I am making a legal claim that the constitutional right to dignity entails the right of individuals to self-determination.

On a practical level, Dr Donkin mentions the possibility of abuse of sick persons. The possibility for abuse exists in many areas of the law, but does not constitute a good reason for blanket prohibitions. The proper way to address foreseeable abuse in the context of voluntary active euthanasia is by putting legal safeguards in place. In surrogacy, for instance, the legal safeguards against abuse include, among others, that any surrogacy agreement must be approved by the High Court before it is put into effect.

Lastly, Dr Donkin contends that I lose sight of the 'human consequences' of euthanasia. Is the vindication - or violation! - of a person's dignity not a 'human consequence'?

\section{Donrich W Jordaan}

School of Law, Howard College, University of KwaZulu-Natal, Durban, South Africa jordaand@ukzn.ac.za

1. Donkin A. Human dignity and the future of the voluntary active euthanasia debate in South Africa. S Afr Med J 2017;107(8):647. https://doi.org/10.7196/SAMJ.2017.v107i8.12599

. Jordaan DW. Human dignity and the future of the voluntary active euthanasia debate in South Africa. S Afr Med J 2017;107(5):383-385. https://doi.org/10.7196/SAMJ.2017.v107i5.12339

. Barkhuizen v Napier [2007] ZACC 5.

4. Barkhuizen v Napier [2007] ZACC 5.

5. British American Tobacco South Africa (Pty) Ltd v Minister of Health [2012] ZASCA 107.

5. British American Tobacco South Africa (Pty) Ltd v Minister of Health [2012] ZASCA 107.
6. Mill JS. On Liberty. 1859. http://www.econlib.org/library/Mill/mlLbty1.html (accessed 4 November 2017).

S Afr Med J 2017;107(12):1050. DOI:10.7196/SAMJ.2017.v107i12.12932 